\title{
Key Factors Affecting Sustainable Tourism in the Region of South Central Coast of Vietnam*
}

\author{
Cong De NGUYEN 1 , Thang Loi NGO ${ }^{2}$, Ngoc My DO ${ }^{3}$, Ngoc Tien NGUYEN ${ }^{4}$
}

Received: September 10, 2020 Revised: November 08, 2020 Accepted: November 16, 2020

\begin{abstract}
Sustainable tourism is the development of tourism activities to meet the current needs of tourists and indigenous peoples while paying attention to the conservation and improvement of resources for the development of tourism activities in the future (World Tourism Organization, 2013). With the aim of identifying factors affecting the development of sustainable tourism in the South Central Coast of Vietnam, the study conducted a typical survey of 160 tourism managers and 240 tourists traveling or have participated in tourism activities of 8 provinces in the South Central Coast of Vietnam, and used the exploratory factor analysis (EFA) analysis and regression analysis for analyzing the data. The research results show that 11 factors impact the development of sustainable tourism in the South Central Coast namely Institutions and policies for tourism development, Infrastructure, Tourism resources, Human resources for tourism, Diversity of tourism services, Relevant support services, Activities of association and cooperation for tourism development, Tourism promotion and encouragement, Tourists' satisfaction, Local community, and Other factors. At the same time, among the above factors, the factors Institutions and policies for tourism development, Infrastructure, Tourism resources, and Local community strongly impact the development of sustainable tourism in the region.
\end{abstract}

Keywords: Regional Tourism Development, Sustainable Tourism, Coastal South Central Vietnam, Vietnam

JEL Classification Code: Z32, R11, Q56, P25

\section{Introduction}

The South Central Coast of Vietnam includes eight provinces - Da Nang, Quang Nam, Quang Ngai, Binh Dinh, Phu Yen, Khanh Hoa, Ninh Thuan, and Binh Thuan with great potential for the activities of the association for the development of sustainable tourism in the region.

This study is an empirical study to determine the factors affecting the development of sustainable tourism in the South

\footnotetext{
*Acknowledgments:

The authors would like to thank the anonymous referees for constructive comments on an earlier version of this paper.

${ }^{1}$ First Author. Office of the People's Committee of Binh Dinh Province, Binh Dinh Province, Vietnam. Email: nguyen.cong.de@gmail.com

${ }^{2}$ Professor, Faculty of Planning and Development, National

Economics University, Vietnam. Email: loint@neu.edu.vn

${ }^{3}$ Associate Professor, Rector, Quy Nhon University, Vietnam. Email: dnmy@qnu.edu.vn

${ }^{4}$ Corresponding Author. Lecturer, Faculty of Economics and Accounting, Quy Nhon University, Binh Dinh, Vietnam [Postal Address: 170 An Duong Vuong, Quy Nhon City, Binh Dinh Province, 55000, Vietnam] Email: nguyenngoctien@qnu.edu.vn

(c) Copyright: The Author(s)

This is an Open Access article distributed under the terms of the Creative Commons Attribution Non-Commercial License (https://creativecommons.org/licenses/by-nc/4.0/) which permits unrestricted non-commercial use, distribution, and reproduction in any medium, provided the original work is properly cited.
}

Central Coast in Vietnam, thereby proposing orientations for the development of regional tourism. To conduct this study, the authors conducted convenience sampling, a method of collecting samples by taking samples that are conveniently located around a location, and surveyed 160 tourism managers and 240 tourists traveling or have participated in tourism activities of the provinces in the South Central Coast of Vietnam, with 400 survey handouts distributed and 400 collected validly, at the rate of $100 \%$.

When developing sustainable tourism at the regional level, the provinces in the region often have to answer a series of questions such as how to develop, which direction to develop, and what factors affect the development of sustainable tourism in the region. According to World Tourism Organization (UNWTO, 2013), "Sustainable tourism is the development of tourism activities to meet the current needs of tourists and indigenous people while paying attention to the conservation and improvement of resources for the development of tourism activities in the future. Sustainable tourism means having a resource management plan to satisfy the economic, social, and aesthetic needs of people while maintaining cultural integrity, biological diversity and life support systems, and essential ecological processes." Accordingly, developing sustainable tourism is an activity that develops tourism in a specific area so that the content, 
form, and scale are appropriate and sustainable over time, without causing environmental degradation or affecting the ability to support other developmental activities.

According to the World Travel \& Tourism Council (WTTC, 2017) "Sustainable tourism development meets the needs of present tourists and host regions while protecting and enhancing opportunity for the future." This definition is short and concise; however, it is too general since it refers to meeting only the needs of current and future visitors without taking into account the needs of the local community, culture, society, ecological environment, and biodiversity.

According to the International Labor Organization (ILO, 2017) "Sustainable tourism consists of three main pillars: social justice, economic development, and environmental integrity. It is a commitment to enhancing local prosperity by maximizing tourism's contribution to the economic prosperity of the destination, from the money tourists spend locally. Tourism creates stable income and jobs for workers without affecting the environment and culture of the tourist destination; ensures the feasibility and competitiveness of the tourist destination and businesses so that they can develop well and bring long-term benefits". With this in mind, development needs to be a positive experience for the locals, tourism companies, workers, and the tourists themselves.

Besides, the development of sustainable tourism in the region is influenced by many factors such as tourism infrastructure (Chen \& Chen, 2011), the participation of the local community (Tsung, 2013; Greg \& Derek, 2010), the participation of tourism businesses (Maia et al., 2005), the involvement of the local government (Lisa, 2012; Muhammet et al., 2010), the system of tourist transport (Hollier \& Lanquar, 1996), etc. Therefore, this study aims to identify three pillars for the development of sustainable tourism in the region: economy, culture, society and environment. The factors affecting activities to develop sustainable tourism in the region include both macro factors and micro factors.

The structure of this study consists of six parts; the next part is an overview of the study; the third part presents the research methodology including research hypothesis, description of the variables of the research model and methods of data collection, data processing; the fourth part presents the research results; the fifth part presents discusses the research findings and the last part presents the conclusion and policy implications of the study.

\section{Literature Review}

First, studies related to the perspective toward the development of sustainable tourism development:

According to the direction of research, the development of sustainable tourism is studied in many different aspects; specifically, aspects of the development of sustainable tourism are represented in the following dimensions:
The first is ecological sustainability. Tirso et al. (1992) thought that it is necessary to assess the tolerance of natural conditions and ecological environment, which is regarded as an important method to assess the impact of the environment and sustainability in the development of sustainable tourism.

The second is social sustainability. Stonich et al. (1995) argued that tourism development in the past had negative impacts on current society including undermining indigenous culture and paving the way for new cultural and social patterns. Sharing this view, Clark (1990) and Ngo (2015) also contended that tourism has great impacts on society, in both positive and negative ways, therefore it is necessary to find the methods of measurement to ease negative impacts on society.

The third is cultural sustainability. Plog (1972), DeKadt (1979), Smith (1989), and Ngo (2015) stated that the interaction relationships, lifestyles, local customs, practices, and traditions can be changed through the introduction of the different habits, styles, customs, and means of communication of tourists to the destinations.

The fourth is economic sustainability. Mowforth and Munt (2015), and Ngo (2015) said that economic sustainability refers to the level of economic benefits from tourism activities. Research shows that tourism activities create a stable income for the local community, contributing to national and regional growth without harming other development conditions in the region.

The fifth is the sustainability of institutions and policies. Unlike Mowforth and Munt (2015) and Ko (2005) who considered environmental management policy as a vital aspect in the development of sustainable tourism, many studies are taking a keen interest in the issues of institutions and policies in the development of sustainable tourism, specifically, Garcia-Melon et al. (2012) said that management and institutions have a strong impact on the development of sustainable tourism. Sharing this view, there are also studies by Azizi (2011), Wang and Pei (2014), Uzun and Somuncu (2015), and Ngo (2015).

The sixth is educational sustainability: Krippendorf (1987) argued that tourism encourages the spread of education and the provision of information about tourists to local people so that they can serve tourists. Sharing this view, there is a study by Whelan (1991).

In summary, the approach to the development of sustainable tourism in the aforementioned aspects of sustainability shows that governments need to pay more attention to the environment, culture, society, economy, and so on in the development of sustainable tourism activities. However, the limitation of these studies is that they only approach each aspect of the development of sustainable tourism, without having identified overall factors that facilitate the development of sustainable tourism. Zhenhua (2003) argued that the debate over sustainable tourism is fragmentary, fragmented, and often flawed with false 
assumptions and arguments. Cevat (2001) argued that the priorities of the national economic policy, the structure of public administration, the emergence of environmental problems, commercialization, and the structure of the international tourism system are all important factors for the development of sustainable tourism in a country. Accordingly, this study aims to define the development of sustainable tourism based on three aspects: economical aspect, socio-cultural aspect and environmental aspect.

Second, studies on factors affecting the development of sustainable tourism:

Referring to factors affecting the development of sustainable tourism, depending on viewpoints toward the development of sustainable tourism, factors affecting the development of sustainable tourism are also mentioned by researchers in a very diverse range, typically the following studies:

Chen and Chen (2011) argued that infrastructure in general and tourism infrastructure, in particular, are in many cases, are the factors determining the success or failure of regional economic development. Tsung (2013) showed that the close connection and participation of the community are important factors affecting the level of support for the development of sustainable tourism. Sharing this view, Greg and Derek (2000) also emphasized the great contribution of the local community to sustainable tourism; without the local community, sustainable tourism activities cannot be ensured, unless, sustainable tourism also brings certain benefits to the local community. Therefore, the development of sustainable tourism and the local community have a dialectical relationship.

Maia et al. (2005) argued that tourism is one of the economic sectors requiring active participation of tourism businesses to diversify tourism products and services to meet the increasing demand in terms of new types of travel needs. Seldjan and Donald (2009) examined the concept of the development of sustainable tourism in urban destinations and showed that there are important similarities and differences between stakeholders (local government, tourism industry cluster, environment offices), especially, the perceptions of different stakeholders have a significant influence on the development of sustainable tourism in urban areas. Lisa (2012) argued that local authorities or institutions should have greater responsibility and participate in planning and developing tourism destinations. Research shows that local governments need to facilitate the agendas of sustainable tourism, and the lack of powerful leadership from industries, top-down directives from state and federal governments, power struggles, and the lack of participation of the local community have contributed to the prevention and inhibition toward the development of sustainable tourism. Sharing this view, Muhammet et al. (2010) also show that complex political systems and power structures in society are important factors in planning and implementing a sustainable tourism policy.

Hollier and Lanquar (1996) argued that to develop sustainable tourism, countries need to build an effective tourist transport system, improve public facilities at tourist destinations, increase support activities at tourist destinations in bad weather, develop appropriate pricing policies for the high and low seasons, and the supply of tourism activities must target specific groups of customers.

From the above studies, it can be seen that many factors affect the development of sustainable tourism, including macro and micro factors such as local authorities, the local community, tourism businesses, tourism infrastructure, stakeholders' perceptions, tourism business environment, and the diversity of tourism products and support services. These elements are applied in the construction of economic, social, and environmental solutions in the author's research as well as attracts the participation of the local community in tourism activities, helping to create jobs, thereby increasing locals' income.

\section{Research Method}

\subsection{Research process}

To do this study, the authors have conducted the following steps to study information diagrams:

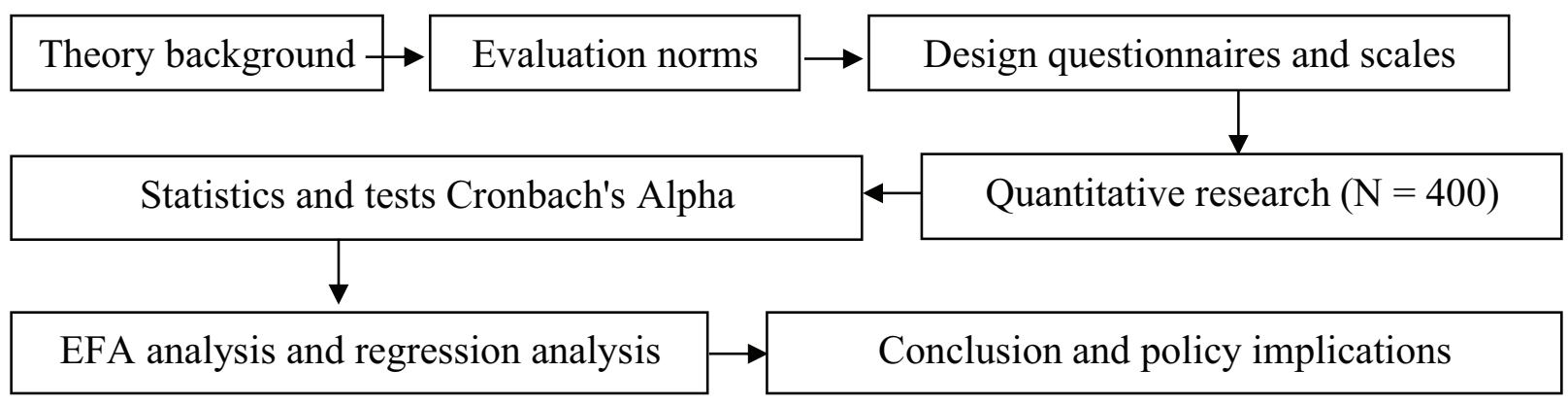

Figure 1: Research process 


\subsection{Hypothesis}

Institutions and policies for tourism development (CS)

Lisa (2012) said that local authorities or institutions have a great influence on the planning and development of tourism destinations, especially tourism destinations in the region, thereby creating value chains in regional tourism development. Sharing this view, there are studies by Muhammet et al. (2010), and Nguyen (2014).

H1: Institutions and policies for tourism development have a positive relationship with the development of sustainable tourism in the South Central Coast.

\section{Infrastructure (HT)}

Chen and Chen (2011) argued that infrastructure in general and tourism infrastructure in particular are the factors determining the success or failure of regional economic development. The same view is seen in Tsung (2013), Greg and Derek (2000), and Pham (2002).

H2: Infrastructure has a positive relationship with the development of sustainable tourism in the South Central Coast.

\section{Tourism resources (TN)}

Mowforth and Munt (2015) argued that the endowed natural landscapes or unique culture are key factors for the development of sustainable tourism; therefore, countries need to preserve landscapes and indigenous cultural values for the development of sustainable tourism. The same view is seen in Nguyen (2015), Nguyen (2014), Nguyen (2013), and Vu et al (2020).

H3: Tourism resources have a positive relationship with the development of sustainable tourism in the South Central Coast.

\section{Human resources for tourism (NL)}

Tran (2011) stated that for tourism development, human resources for tourism have a great influence on sustainable development; human resources here are understood as human resources directly serving the tourism industry such as employees working in tourism businesses and also officials working in tourism authorities in the locality. The same view is seen in Maia et al. (2005), Nguyen et al. (2019), and HareeBin (2020).

H4: Human resources for tourism have a positive relationship with the development of sustainable tourism in the South Central Coast.

\section{Diversity of tourism services (SP)}

Maia et al. (2005) showed that the process of exploiting the culture, history, tourism resources, etc, create tourism products (such as programs, tours, routes, etc). Accordingly, research has proven that the diversity of tourism services in tourism destinations have a great influence on the development of sustainable tourism in the destinations. Sharing this view, there are studies by Nguyen (2013) and Nguyen et al. (2019).

H5: Diversity of tourism services have a positive relationship with the development of sustainable tourism in the South Central Coast.

\section{Relevant Support Services (DV)}

Hollier and Lanquar (1996) argued that tourism-related support services such as the system of transport agencies, health systems, insurance, banking, etc. have a great influence on tourism activities of tourists at the destination. Sharing this view, there are studies by Nguyen (2013) and Nguyen et al. (2019).

H6: Relevant support services have a positive relationship with the development of sustainable tourism in the South Central Coast.

The activities of association and cooperation for tourism development (LK)

Dwyer et al. (2011) argued that there is a close relationship between supply and demand in developing sustainable tourism activities. Chheang (2013) also said that the role of the association in tourism development in Asian countries during the period of Asian integration affected the development of sustainable tourism among countries in the Asian group and the whole region. Sharing this view, there are studies by Tisdell (2013), Hilal et al. (2010), and Nguyen et al. (2019).

H7: The activities of association and cooperation for tourism development have a positive relationship with the development of sustainable tourism in the South Central Coast.

\section{Tourism promotion and encouragement $(Q B)$}

Wray et al. (2010) argued that the marketing for tourism destinations is an option of "best practice or best travel destination" or "local marketing in tourism development" which attracts visitors and needs to be planned in the best way, managed by the local government and widely advertised in the media. Similarly, Tisdell (2013) argued that the demands of tourists come from the consumption taste; therefore, in the process of providing tourism services, countries as well as localities, tourist destinations, tourism businesses need to strengthen the activities of promotion and encouragement for tourism which need to have depth and impress and attract potential tourists. Sharing this view, there are studies by Hilal et al. (2010), and Nguyen et al. (2019). 
H8: The activities of promotion and encouragement for tourism have a positive relationship with the development of sustainable tourism in the South Central Coast.

\section{Tourists'satisfaction (HL)}

Dimoska and Petrevska (2012) argued that sustainable tourism cannot be considered a special form of tourism. Instead, all segments and components of the tourism industry need to be sustainable; therefore, the authors argue that to develop sustainable tourism both the supply (tourism product suppliers) and the demand (tourism product users) need to be assessed. According to the research, the satisfaction of people who use tourism products is the decisive factor for their return; this is the factor affecting the sustainable development of tourism products or tourist destinations. Sharing this view, there are studies by Ko (2005), Viljoen (2007), Sedai (2006), Nguyen et al. (2019), etc.

H9: Tourists' satisfaction has a positive relationship with the development of sustainable tourism in the South Central Coast.

\section{Local community (CD)}

Greg and Derek (2000) showed the contribution of the local community to sustainable tourism; without the local community, sustainable tourism cannot be ensured, unless, sustainable tourism also brings certain benefits to the local community; thereby showing the dialectical relationship between the development of sustainable tourism and the local community. Sharing this view, there are studies by Tsung (2013), Ngo (2015), Chamidah et al. (2020), etc.
H10: Local community has a positive relationship with the development of sustainable tourism in the South Central Coast.

\section{Other factors (K)}

Tirso et al (1992) suggested that climate change and natural disasters affect the tolerance of tourism resources, ecological environment, etc, thus affecting tourism development activities. Also, the study of Sharpley (2010) showed the limitations of current tourism models and proposed a different approach that allows maintaining sustainability to the impacts of environmental factors and natural disasters, and is seen as a prerequisite for sustainable tourism. Similarly, Nguyen et al. (2020) also argued that industrial revolution 4.0 also has a certain impact on tourism development through the development of tourism apps or the programs of international economic association and integration.

H11: Other factors (such as climate change, natural disasters, industrial revolution 4.0 , etc) have a positive relationship with the development of sustainable tourism in the South Central Coast.

\subsection{Research Model}

Based on research hypotheses, the authors proposed that the research model is a multivariate regression model with the dependent variables (economy, socio-cultural, and environment) of the development of sustainable tourism in the South Central Coast of Vietnam, and 11 independent variables stated in each hypothesis of the study.

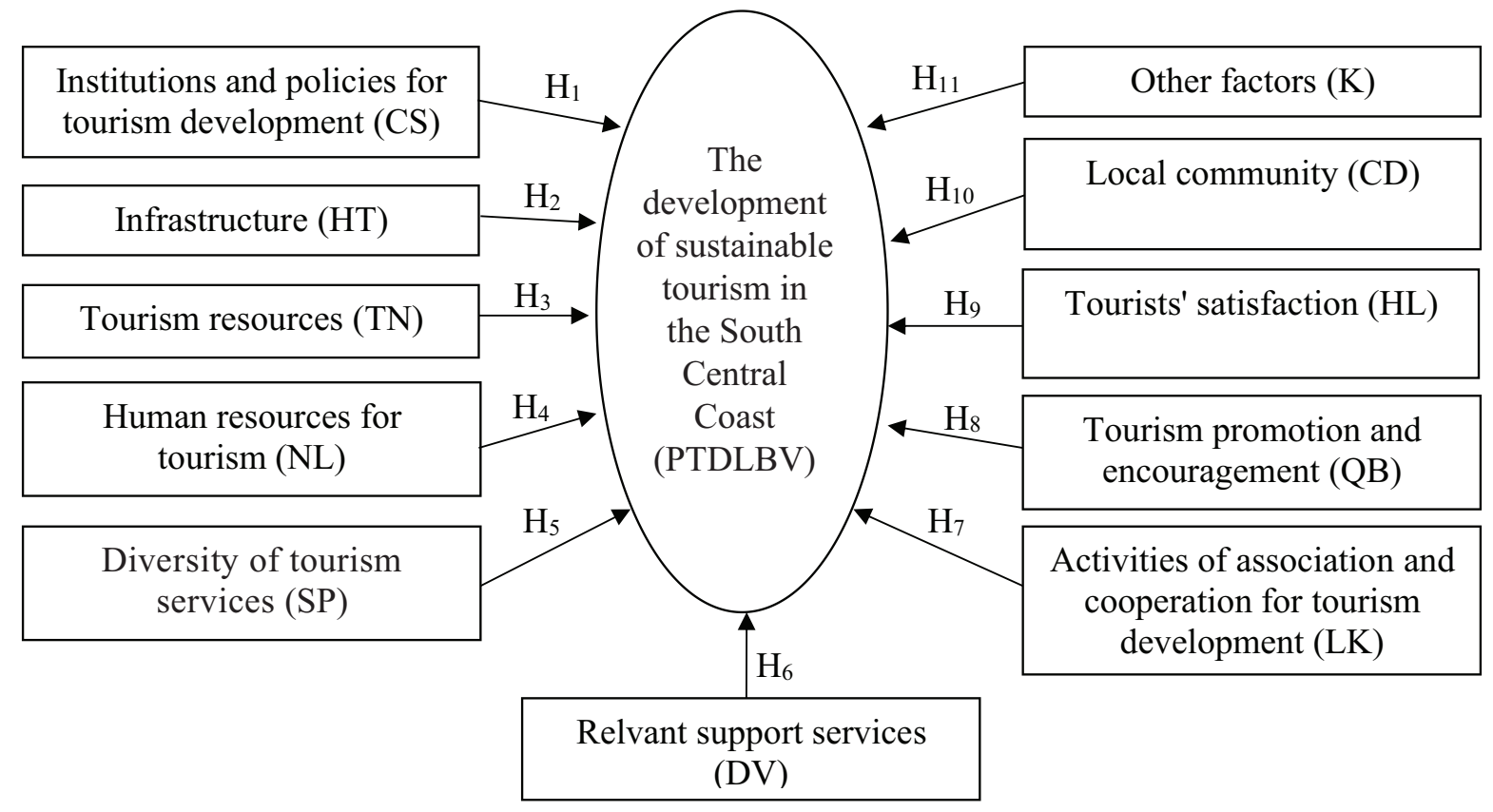

Figure 2: Overview of the Research Model 
From the proposed model above, the authors propose an expected research equation as follows:

$$
\begin{aligned}
\mathrm{PTDLBV}= & \alpha+\beta 1 * \mathrm{CS}+\beta 2 * \mathrm{HT}+\beta 3 * \mathrm{TN}+\beta 4 * \mathrm{NL} \\
& +\beta 5 * \mathrm{SP}+\beta 6^{*} \mathrm{DV}+\beta 7 * \mathrm{LK}+\beta 8^{*} \mathrm{QB} \\
& +\beta 9 * \mathrm{HL}+\beta 10 * \mathrm{DC}+\beta 11 * \mathrm{~K}+\varepsilon
\end{aligned}
$$

Where: $\alpha, \beta 1, \beta 2, \beta 3, \beta 4, \beta 5, \beta 6, \beta 7, \beta 8, \beta 9, \beta 10$ and $\beta 11$ are coefficients

$\varepsilon$ : is error

\subsection{Variables of the Research Model}

To serve the process of questioning and answering the survey handouts, the authors use the Likert scale (5 options), the ratings on this scale are as follows: $1=$ "very low", 2 = "low ", 3 =" medium ", 4 =" high ", 5 =" very high ".
The variables and scales of the research model are determined as follows:

\subsection{Way to Collect Data}

To collect data for the study, the authors used a predesigned survey based on the defined variables and scales. The final survey questionnaire was constructed based on 3 phases.

Phase 1, Developing the draft survey questionnaire: The authors conducted an overview of domestic and foreign studies on the development of sustainable tourism to identify gaps that need to be examined. Next, from the theory on the development of sustainable tourism and preliminary data of tourism development in the South Central Coast of Vietnam, the authors wrote draft survey questionnaires including 2 parts, namely: (i) general information about the

\begin{tabular}{|c|c|c|c|c|}
\hline NO & Factors & Observed variables & Encryption & Source \\
\hline \multicolumn{5}{|c|}{ Dependent variables } \\
\hline \multirow{10}{*}{1} & \multirow{10}{*}{$\begin{array}{l}\text { Economic } \\
\text { aspect }(\mathrm{KT})\end{array}$} & Tourism contributes to local income (GPDR) & KT1 & \multirow{10}{*}{$\begin{array}{c}\text { Mowforth and } \\
\text { Munt (2015); Ngo } \\
\text { (2015); UNWTO } \\
\text { (2013); WTTC } \\
\text { (2017); ILO (2017) } \\
\text { and surveyed } \\
\text { experts }\end{array}$} \\
\hline & & $\begin{array}{l}\text { Tourism promotes the development of other economic } \\
\text { branches and changes the local economic structure in a } \\
\text { positive direction }\end{array}$ & KT2 & \\
\hline & & $\begin{array}{l}\text { Tourism contributes to promoting the local image and } \\
\text { attracting investment }\end{array}$ & KT3 & \\
\hline & & $\begin{array}{l}\text { Tourism increases the amount of consumption of local } \\
\text { products, goods, and services }\end{array}$ & KT4 & \\
\hline & & $\begin{array}{l}\text { Tourism creates new opportunities for business investment } \\
\text { for businesses and the local community }\end{array}$ & KT5 & \\
\hline & & $\begin{array}{l}\text { Tourism contributes to increasing income and economic } \\
\text { accumulation for the local community }\end{array}$ & KT6 & \\
\hline & & $\begin{array}{l}\text { Tourism contributes to improving job opportunities in the } \\
\text { region }\end{array}$ & KT7 & \\
\hline & & $\begin{array}{l}\text { Prices of products, goods, and services increase with } \\
\text { tourism }\end{array}$ & KT8 & \\
\hline & & $\begin{array}{l}\text { Tourism creates opportunities for developing the digital } \\
\text { economy in the region }\end{array}$ & KT9 & \\
\hline & & $\begin{array}{l}\text { Tourism contributes to promoting international economic } \\
\text { integration }\end{array}$ & KT10 & \\
\hline
\end{tabular}
respondents, (ii) survey information.

Table 1: Variables and scales used 
Table 1: Continued

\begin{tabular}{|c|c|c|c|c|}
\hline NO & Factors & Observed variables & Encryption & Source \\
\hline \multicolumn{5}{|c|}{ Dependent variables } \\
\hline \multirow{12}{*}{2} & \multirow{12}{*}{$\begin{array}{l}\text { Socio-cultural } \\
\text { aspect }(\mathrm{XH})\end{array}$} & $\begin{array}{l}\text { Tourism contributes to preserving and developing the } \\
\text { heritage values, local culture, customs, and practices }\end{array}$ & $\mathrm{XH} 1$ & \multirow{12}{*}{$\begin{array}{l}\text { DeKadt (1979); } \\
\text { Plog (1972); Smith } \\
\text { (1989); Stonich } \\
\text { et al. (1995); } \\
\text { Clark (1990), Ngo } \\
\text { (2015); UNWTO } \\
\text { (2013), WTTC } \\
\text { (2017), ILO } \\
\text { (2017); HareeBin } \\
\text { (2020); Purnomo } \\
\text { et al. (2020) and } \\
\text { surveyed experts }\end{array}$} \\
\hline & & $\begin{array}{l}\text { Tourism contributes to diversifying entertainment services for } \\
\text { the locality }\end{array}$ & $\mathrm{XH} 2$ & \\
\hline & & $\begin{array}{l}\text { Tourism contributes to stabilizing livelihoods and improving } \\
\text { the material and spiritual life of local people }\end{array}$ & $\mathrm{XH} 3$ & \\
\hline & & Tourism facilitates cultural exchange for local people & $\mathrm{XH} 4$ & \\
\hline & & $\begin{array}{l}\text { Tourism increases the participation of residents in local } \\
\text { activities }\end{array}$ & $\mathrm{XH} 5$ & \\
\hline & & $\begin{array}{l}\text { Tourism creates pressure to improve the quality of medical } \\
\text { services, ensure food safety and hygiene, public hygiene, } \\
\text { and local disease control. }\end{array}$ & $\mathrm{XH} 6$ & \\
\hline & & $\begin{array}{l}\text { Tourism creates pressure to enhance the work of ensuring } \\
\text { local social order and security }\end{array}$ & $\mathrm{XH} 7$ & \\
\hline & & $\begin{array}{l}\text { Tourism contributes to improving the capacity of public } \\
\text { administration in the locality }\end{array}$ & $\mathrm{XH} 8$ & \\
\hline & & $\begin{array}{l}\text { Tourism contributes to improving the intellectual standards of } \\
\text { the local community }\end{array}$ & $\mathrm{XH} 9$ & \\
\hline & & Tourism undermines indigenous cultural values & $\mathrm{XH} 10$ & \\
\hline & & $\begin{array}{l}\text { Tourism raises social problems such as crime, drugs, } \\
\text { prostitution, and so on. }\end{array}$ & $\mathrm{XH} 11$ & \\
\hline & & Tourism causes rich and poor disparities and social inequality & $\mathrm{XH} 12$ & \\
\hline \multirow{9}{*}{3} & \multirow{9}{*}{$\begin{array}{l}\text { Environmental } \\
\text { aspect (MT) }\end{array}$} & $\begin{array}{l}\text { Tourism contributes to the effective conservation and } \\
\text { exploitation of natural resources (water, air, land, etc) }\end{array}$ & MT1 & \multirow{9}{*}{$\begin{array}{c}\text { Tirso (1992); Ngo } \\
\text { (2015); Nguyen } \\
\text { (2014); UNWTO } \\
\text { (2013); WTTC } \\
\text { (2017); ILO (2017) } \\
\text { and surveyed } \\
\text { experts }\end{array}$} \\
\hline & & $\begin{array}{l}\text { Tourism contributes to raising awareness of environmental } \\
\text { protection }\end{array}$ & MT2 & \\
\hline & & $\begin{array}{l}\text { Tourism contributes to the conservation of biodiversity, } \\
\text { ecosystems, and landscapes }\end{array}$ & MT3 & \\
\hline & & $\begin{array}{l}\text { Tourism contributes to improving environmental regulations } \\
\text { and policies }\end{array}$ & MT4 & \\
\hline & & $\begin{array}{l}\text { Tourism promotes the production and consumption of } \\
\text { environmentally friendly goods and services }\end{array}$ & MT5 & \\
\hline & & Tourism increases environmental pollution & MT6 & \\
\hline & & $\begin{array}{l}\text { Tourism generates large amounts of waste (domestic, solid, } \\
\text { plastic, etc) that need treatment }\end{array}$ & MT7 & \\
\hline & & $\begin{array}{l}\text { Tourism greatly affects the diverse development of natural } \\
\text { ecosystems (forests, seas, animals, plants). }\end{array}$ & MT8 & \\
\hline & & $\begin{array}{l}\text { Tourism has a negative impact on the living environment and } \\
\text { causes problems of overload (traffic, living space, etc) for } \\
\text { residents living in a tourist hotspot. }\end{array}$ & MT9 & \\
\hline
\end{tabular}


Table 1: Continued

\begin{tabular}{|c|c|c|c|c|}
\hline NO & Factors & Observed variables & Encryption & Source \\
\hline \multicolumn{5}{|c|}{ Independent variables } \\
\hline \multirow{6}{*}{1} & \multirow{6}{*}{$\begin{array}{l}\text { Institutions } \\
\text { and policies } \\
\text { for tourism } \\
\text { development } \\
\text { (CS) }\end{array}$} & $\begin{array}{l}\text { Perspectives and investment policies for tourism } \\
\text { development }\end{array}$ & CS1 & \multirow{6}{*}{$\begin{array}{l}\text { Lisa (2012); } \\
\text { Muhammet et al. } \\
\text { (2010); Nguyen } \\
\text { (2014); García-Melon } \\
\text { et al. (2012); Wang } \\
\text { and Pei (2014) and } \\
\text { surveyed experts }\end{array}$} \\
\hline & & Business and investment environment & & \\
\hline & & $\begin{array}{l}\text { Strategic orientation of tourism development and } \\
\text { construction of tours, routes, tourist sites, tourist areas }\end{array}$ & CS2 & \\
\hline & & State management of tourism & CS3 & \\
\hline & & $\begin{array}{l}\text { Policies on mobilizing and allocating resources for tourism } \\
\text { development }\end{array}$ & CS4 & \\
\hline & & $\begin{array}{l}\text { Policies on supporting investors, tourism businesses, local } \\
\text { communities, and tourists }\end{array}$ & CS5 & \\
\hline \multirow{5}{*}{2} & \multirow{5}{*}{$\begin{array}{l}\text { Infrastructure } \\
(\mathrm{HT})\end{array}$} & $\begin{array}{l}\text { Convenient transportation infrastructure and airport } \\
\text { system, pier, station meet the needs of visitors }\end{array}$ & HT1 & \multirow{5}{*}{$\begin{array}{c}\text { Chen and Chen } \\
\text { (2011); Tsung (2013); } \\
\text { Greg and Derek } \\
\text { (2000); Pham (2002) } \\
\text { and surveyed experts }\end{array}$} \\
\hline & & $\begin{array}{l}\text { A rich system of tours, routes, tourist spots, and tourist } \\
\text { resorts }\end{array}$ & HT2 & \\
\hline & & $\begin{array}{l}\text { Information technology infrastructure meet the needs of } \\
\text { tourists }\end{array}$ & HT3 & \\
\hline & & $\begin{array}{l}\text { Adequate system of hotels, restaurants, entertainment, } \\
\text { shopping, and entertainment venues }\end{array}$ & HT4 & \\
\hline & & Adequate and clean public toilet system & HT5 & \\
\hline \multirow{5}{*}{3} & \multirow{5}{*}{$\begin{array}{l}\text { Tourism } \\
\text { resources } \\
\text { (TN) }\end{array}$} & $\begin{array}{l}\text { Natural landscapes (hills, rivers, lakes, beaches, bays, } \\
\text { lagoons, islands, peninsulas, etc) are beautiful, diverse, } \\
\text { and unique }\end{array}$ & TN1 & \multirow{5}{*}{$\begin{array}{c}\text { Mowforth and Munt } \\
\text { (2015); Nguyen } \\
\text { (2015); Nguyen } \\
\text { (2014); Nguyen } \\
\text { (2013); Vu et al. } \\
\text { (2020) and surveyed } \\
\text { experts }\end{array}$} \\
\hline & & $\begin{array}{l}\text { Many impressive and unique cultural heritages, } \\
\text { architectural art, historical relics, museums, monuments, } \\
\text { pagodas, churches, etc }\end{array}$ & TN2 & \\
\hline & & $\begin{array}{l}\text { Many interesting and unique cultural events, sports, and } \\
\text { traditional festivals }\end{array}$ & TN3 & \\
\hline & & Many special traditional arts and folklore & TN4 & \\
\hline & & $\begin{array}{l}\text { Many unique traditional craft villages, handicrafts, local } \\
\text { products. }\end{array}$ & TN5 & \\
\hline \multirow{5}{*}{4} & \multirow{5}{*}{$\begin{array}{l}\text { Human } \\
\text { resources for } \\
\text { tourism } \\
(\mathrm{NL})\end{array}$} & $\begin{array}{l}\text { Perspectives and strategies for human resources } \\
\text { development }\end{array}$ & NL1 & \multirow{5}{*}{$\begin{array}{l}\text { Tran (2011); Maia } \\
\text { et al (2005); Nguyen } \\
\text { et al. (2019); } \\
\text { HareeBin (2020) and } \\
\text { surveyed experts }\end{array}$} \\
\hline & & $\begin{array}{l}\text { Policies on training, retraining, and attracting human } \\
\text { resources }\end{array}$ & NL2 & \\
\hline & & Remuneration and working environment & NL3 & \\
\hline & & $\begin{array}{l}\text { The quality of human resources for state management of } \\
\text { tourism }\end{array}$ & NL4 & \\
\hline & & The quality of human resources of tourism businesses & NL5 & \\
\hline \multirow{5}{*}{5} & \multirow{5}{*}{$\begin{array}{l}\text { Diversity of } \\
\text { tourism services } \\
\text { (SP) }\end{array}$} & Diversified and fully equipped accommodation & SP1 & \multirow{5}{*}{$\begin{array}{c}\text { Maia et al (2005); } \\
\text { Nguyen (2013); } \\
\text { Nguyen et al. (2019) } \\
\text { and surveyed experts }\end{array}$} \\
\hline & & Many interesting and rich entertainment activities & SP2 & \\
\hline & & Many attractive tours, routes, and tourist destinations & SP3 & \\
\hline & & Food, dining, and local cuisine are unique and attractive & SP4 & \\
\hline & & Transportation to serve tourists is diverse & SP5 & \\
\hline
\end{tabular}


Table 1: Continued

\begin{tabular}{|c|c|c|c|c|}
\hline NO & Factors & Observed variables & Encryption & Source \\
\hline \multicolumn{5}{|c|}{ Independent variables } \\
\hline \multirow{5}{*}{6} & \multirow{5}{*}{$\begin{array}{l}\text { Relevant support } \\
\text { services } \\
\text { (DV) }\end{array}$} & Medical system & DV1 & \multirow{5}{*}{$\begin{array}{l}\text { Hollier and Lanquar } \\
\text { (1996); Nguyen et al. } \\
\text { (2019) and surveyed } \\
\text { experts }\end{array}$} \\
\hline & & Information channel for tourists & DV2 & \\
\hline & & system for tourists & DV3 & \\
\hline & & Tourist insurance & DV4 & \\
\hline & & Tourist security & DV5 & \\
\hline \multirow{5}{*}{7} & \multirow{5}{*}{$\begin{array}{l}\text { The activities } \\
\text { of association } \\
\text { and cooperation } \\
\text { for tourism } \\
\text { development } \\
\text { (LK) }\end{array}$} & Institution of regional association in tourism development & LK1 & \multirow{5}{*}{$\begin{array}{l}\text { Dwyer et al (2011); } \\
\text { Chheang (2013); } \\
\text { Tisdell (2013); Hilal } \\
\text { et al. (2010); Nguyen } \\
\text { et al. (2019) and } \\
\text { surveyed experts }\end{array}$} \\
\hline & & $\begin{array}{l}\text { Association in exploiting tours, routes, points, tourist areas } \\
\text { of the region }\end{array}$ & LK2 & \\
\hline & & $\begin{array}{l}\text { Association in using and developing tourism human } \\
\text { resources }\end{array}$ & LK3 & \\
\hline & & $\begin{array}{l}\text { Association in investing infrastructure for tourism, } \\
\text { promoting and encouraging regional tourism }\end{array}$ & LK4 & \\
\hline & & Association in issuing general policies on tourism & LK5 & \\
\hline \multirow{5}{*}{8} & \multirow{5}{*}{$\begin{array}{l}\text { Tourism } \\
\text { promotion and } \\
\text { encouragement } \\
\text { (QB) }\end{array}$} & Promotion and encouragement strategy & QB1 & \multirow{5}{*}{$\begin{array}{l}\text { Wray et al (2010); } \\
\text { Tisdell (2013); Hilal } \\
\text { et al. (2010); Nguyen } \\
\text { et a.I (2019) and } \\
\text { surveyed experts }\end{array}$} \\
\hline & & Make good use of new and traditional market opportunities & QB2 & \\
\hline & & Development of general programs and events & QB3 & \\
\hline & & The promotion of new markets & QB4 & \\
\hline & & $\begin{array}{l}\text { The promotion and encouragement of local and regional } \\
\text { tourism }\end{array}$ & QB5 & \\
\hline \multirow{5}{*}{9} & \multirow{5}{*}{$\begin{array}{l}\text { Tourists' } \\
\text { satisfaction } \\
\text { (HL) }\end{array}$} & The organization of tourism activities & HL1 & \multirow{5}{*}{$\begin{array}{c}\text { Dimoska \& Petrevska } \\
\text { (2012); Ko (2005); } \\
\text { Viljoen (2007); Sedai } \\
\text { (2006); Nguyen et al. } \\
\text { (2019) and surveyed } \\
\text { experts }\end{array}$} \\
\hline & & Local impression & HL2 & \\
\hline & & The experience provides fun and satisfaction & HL3 & \\
\hline & & Return of tourists & $\mathrm{HL} 4$ & \\
\hline & & $\begin{array}{l}\text { Images of the locality, the region, and the tourism services } \\
\text { of the locality and the region are introduced }\end{array}$ & HL5 & \\
\hline \multirow{3}{*}{10} & \multirow{3}{*}{$\begin{array}{l}\text { Local community } \\
\text { (CD) }\end{array}$} & $\begin{array}{l}\text { The local community actively participates in tourism } \\
\text { development and business }\end{array}$ & CD1 & \multirow{3}{*}{$\begin{array}{c}\text { Greg \& Derek (2000); } \\
\text { Tsung (2013); } \\
\text { Chamidah et al. } \\
\text { (2020) and surveyed } \\
\text { experts }\end{array}$} \\
\hline & & Friendly local community & CD2 & \\
\hline & & The local community assists visitors & CD3 & \\
\hline \multirow{3}{*}{11} & \multirow{3}{*}{$\begin{array}{l}\text { Other factors } \\
(\mathrm{K})\end{array}$} & Impacts of climate change and natural disasters & $\mathrm{K} 1$ & \multirow{3}{*}{$\begin{array}{c}\text { Tirso et al (1992); } \\
\text { Sharpley (2010); } \\
\text { Nguyen et al (2020) } \\
\text { and surveyed experts }\end{array}$} \\
\hline & & The process of international economic integration & K2 & \\
\hline & & Industrial Revolution 4.0 & K3 & \\
\hline
\end{tabular}


Phase 2, Consulting experts and investigating to complete the scales, observed variables, etc which need to be surveyed: In this phase, the authors conducted direct interviews and consultations with experts, specifically lecturers of universities, research institutes, domestic and international tourists, with totally 40 people involved. At this stage, the authors conducted direct interviews about the survey questionnaires designed in phase 1 and exchanged research ideas with experts and visitors to check whether the survey was appropriate or not and whether it is necessary to supplement or adjust the scales and observed variables accordingly.

Phase 3, Designing the official questionnaire: Based on the results of the interviews in phase 2, the authors synthesized and produced a complete survey questionnaire and to increase the efficiency, accuracy, and feasibility of the survey, the authors held seminars with experts who are lecturers from universities and research institutes to continue receiving more comments from experts to complete the final survey questionnaire.

At the same time, the survey of 400 tourists was done by having the surveyors meet directly with each visitor to interview them face-to-face, and also to ensure that the representativeness of the study, that is, tourists taking part in the survey must consist of international tourists and domestic tourists who have been participating in tourism activities of the provinces in the South Central Coast of Vietnam.

\subsection{Methods of Data Analysis}

From the survey handouts validly collected, the authors transferred data to Excel, coding variables for each part of the survey. Next, all of the data were put into SPSS 22.0 software. The authors conducted different analysis and testing, for analyzing data, on SPSS software as follows:

Cronbach's Alpha analysis: The purpose of Cronbach's Alpha analysis is to test the reliability of the scale and survey data to evaluate the correlation between the observed variables that are the influencing factors in the survey to see if the observed variables are closely related to one another in measuring the impact level of test factors on the development of sustainable tourism. Most researchers accept Cronbach's Alpha's 0.8 or higher as good; 0.7 to 0.8 is usable and if the concepts in question are new then the coefficient should be just above 0.6. With Cronbach's Alpha level greater than or equal to 0.8 , the scale is considered a good measure, the questions are closely designed, the scales are correlated to achieve high reliability (Hoang \& Chu, 2011).

Exploratory factor analysis (EFA): When analyzing discovery factors, researchers often care about some standards.

First, Kaiser-Meyer-Olkin (KMO) coefficient $\geq 0.5$, the significance level of the Bartlett $\leq 0.05$ test. $\mathrm{KMO}$ is a criterion used to consider the appropriateness of EFA, 0.5 $\leq \mathrm{KMO} \leq 1$, then factor analysis is appropriate. Bartlett's Test examined the hypothesis of the correlation between zero observed variables overall. If this test is statistically significant $(\mathrm{Sig} \leq 0.05)$, the observed variables are correlated overall

Second, factor loading coefficient $>0.45$. If any observed variable has a factor loading coefficient $\leq 0.45$, it will be disqualified. Third, the scale is accepted when the total variance extracted $\geq 50 \%$ and the eigenvalue is greater than 1. Fourth, there must be a difference in factor loading coefficient of an observed variable among factors $\geq 0.3$ to ensure the distinguishing value among factors is protected (Hoang \& Chu, 2011). According to Dinh et al. (2018), factor loading is the norm to ensure the practical meaning of EFA. Factor loading $>0.3$ is considered to be the minimum, factor loading $>0.4$ is considered important, factor loading $\geq 0.5$ is considered to have practical significance.

\section{Research Results}

\subsection{Cronbach's Alpha}

In this study, the observed variables of the independent and dependent variables are selected when the Cronbach's Alpha coefficients are 0.6 or higher and the total variable correlation is greater than 0.3 . The results shown in Table 2 demonstrate that the variables in the research model are reliable

Test results also show that Cronbach's Alpha of the dependent and independent variables are both greater than 0.7 . Thus, both the dependent variables and the independent variables are satisfactory in terms of reliability, so no variable is removed. Hence, the test results of the scales show that all scales are consistent and reliable, and statistically significant to use the EFA discovery factor analysis for the development of sustainable tourism in the South Central Coast of Vietnam.

\subsection{Exploratory Factor Analysis (EFA)}

Based on testing reliability and correlation by Cronbach's Alpha, the authors analyzed the EFA discovery factor, and the results are as follows:

According to the KMO table and Bartlett's test, we have $\mathrm{KMO}$ coefficient $=0.717>0.5$ (greater than the minimum to ensure proper EFA analysis) and the Sig level of Bartlett's test is $0.000<0.05$, which means that the variables correlate in general. Thus, the EFA analysis for the independent variables is significant.

The analytical results in Table 3 show that according to the Eigenvalue $>1$ standard, 11 groups of factors were drawn. The total variance extracted is $72.591 \%$ (greater than the standard level $>50 \%$ ), which means $72.591 \%$ variation of the data is explained by 11 groups of factors. 
Table 2: Cronbach's Alpha Coefficient of the Independent Variables and the Dependent Variables

\begin{tabular}{|c|c|c|c|}
\hline Reliability Statistics & Encryption & No. of Items & $\begin{array}{c}\text { Cronbach's } \\
\text { Alpha }\end{array}$ \\
\hline \multicolumn{4}{|l|}{ 1. For the dependent variables } \\
\hline - Economic aspect & KT & 10 & 0.828 \\
\hline - Socio-cultural aspect & $\mathrm{XH}$ & 12 & 0.765 \\
\hline - Environmental aspect & MT & 09 & 0.879 \\
\hline \multicolumn{4}{|l|}{ 2. For independent variables } \\
\hline - Institutions and policies for tourism development & CS & 06 & 0.894 \\
\hline - Infrastructure & HT & 05 & 0.839 \\
\hline - Tourism resources & $\mathrm{TN}$ & 05 & 0.929 \\
\hline - Human resources for tourism & NL & 05 & 0.896 \\
\hline - Diversity of tourism services & SP & 05 & 0.910 \\
\hline - Relevant support services & DV & 05 & 0.899 \\
\hline $\begin{array}{l}\text { - Activities of association and cooperation for tourism } \\
\text { development }\end{array}$ & LK & 05 & 0.863 \\
\hline - Tourism promotion and encouragement & QB & 05 & 0.927 \\
\hline - Tourists' satisfaction & $\mathrm{HL}$ & 05 & 0.936 \\
\hline - Local community & CD & 03 & 0.739 \\
\hline - Other factors & $\mathrm{K}$ & 03 & 0.769 \\
\hline
\end{tabular}

Table 3: The Results of Total Variation of the Data

\begin{tabular}{|l|c|c|c|c|c|c|c|c|c|}
\hline \multirow{2}{*}{ Component } & \multicolumn{3}{|c|}{ Initial Eigenvalues } & \multicolumn{2}{c|}{$\begin{array}{c}\text { Extraction Sums of Squared } \\
\text { Loadings }\end{array}$} & \multicolumn{3}{c|}{$\begin{array}{c}\text { Rotation Sums of Squared } \\
\text { Loadings }\end{array}$} \\
\cline { 2 - 10 } & Total & $\begin{array}{c}\% \text { of } \\
\text { Variance }\end{array}$ & $\begin{array}{c}\text { Cumulative } \\
\%\end{array}$ & Total & $\begin{array}{c}\% \text { of } \\
\text { Variance }\end{array}$ & $\begin{array}{c}\text { Cumulative } \\
\%\end{array}$ & \multicolumn{2}{c|}{ Total } & \multicolumn{2}{c}{$\begin{array}{c}\text { of } \\
\text { Variance }\end{array}$} & $\begin{array}{c}\text { Cumulative } \\
\%\end{array}$ \\
\hline 1 & 6.634 & 12.757 & 12.757 & 6.634 & 12.757 & 12.757 & 4.035 & 7.759 & 7.759 \\
\hline 2 & 6.012 & 11.562 & 24.320 & 6.012 & 11.562 & 24.320 & 3.995 & 7.683 & 15.442 \\
\hline 3 & 4.170 & 8.020 & 32.339 & 4.170 & 8.020 & 32.339 & 3.994 & 7.680 & 23.123 \\
\hline 4 & 3.822 & 7.349 & 39.688 & 3.822 & 7.349 & 39.688 & 3.967 & 7.629 & 30.752 \\
\hline 5 & 3.449 & 6.633 & 46.321 & 3.449 & 6.633 & 46.321 & 3.760 & 7.231 & 37.983 \\
\hline 6 & 3.136 & 6.030 & 52.351 & 3.136 & 6.030 & 52.351 & 3.747 & 7.205 & 45.189 \\
\hline 7 & 2.848 & 5.477 & 57.828 & 2.848 & 5.477 & 57.828 & 3.681 & 7.079 & 52.267 \\
\hline 8 & 2.503 & 4.813 & 62.641 & 2.503 & 4.813 & 62.641 & 3.307 & 6.360 & 58.628 \\
\hline 9 & 2.045 & 3.932 & 66.573 & 2.045 & 3.932 & 66.573 & 3.162 & 6.081 & 64.709 \\
\hline 10 & 1.768 & 3.400 & 69.973 & 1.768 & 3.400 & 69.973 & 2.061 & 3.964 & 68.672 \\
\hline 11 & 1.361 & 2.618 & 72.591 & 1.361 & 2.618 & 72.591 & 2.037 & 3.918 & 72.591 \\
\hline 12 & .976 & 1.878 & 74.468 & & & & & \\
\hline
\end{tabular}

Extraction Method: Principal Component Analysis. 
Besides, when using Varimax rotation to obtain the best load factor, 11 groups of influencing factors were obtained, including: (1) Tourists' satisfaction (5 variables); (2) Institutions and policies for tourism development (5 variables); (3) Tourism promotion an encouragement (5 variables); (4) Tourism resources (5 variables);
(5) Relevant support services (5 variables); (6) Diversity of tourism services (5 variables); (7) Human resources for tourism (5 variables); (8) Activities of association cooperation for tourism development (5 variables); (9) Infrastructure (5 variables); (10) Other factors (3 variables) and (11) Local community (3 variables) (see Table 4).

Table 4: The Factor Transformation Matrix

\begin{tabular}{|c|c|c|c|c|c|c|c|c|c|c|c|}
\hline & & & & & & Comp & & & & & \\
\hline & 1 & 2 & 3 & 4 & 5 & 6 & 7 & 8 & 9 & 10 & 11 \\
\hline HL1 & .935 & & & & & & & & & & \\
\hline HL2 & .929 & & & & & & & & & & \\
\hline HL3 & .902 & & & & & & & & & & \\
\hline HL4 & .838 & & & & & & & & & & \\
\hline HL5 & .805 & & & & & & & & & & \\
\hline CS5 & & .837 & & & & & & & & & \\
\hline CS1 & & .836 & & & & & & & & & \\
\hline CS2 & & .823 & & & & & & & & & \\
\hline CS6 & & .806 & & & & & & & & & \\
\hline CS3 & & .754 & & & & & & & & & \\
\hline CS4 & & .744 & & & & & & & & & \\
\hline QB5 & & & .909 & & & & & & & & \\
\hline QB2 & & & .854 & & & & & & & & \\
\hline QB1 & & & .853 & & & & & & & & \\
\hline QB3 & & & .816 & & & & & & & & \\
\hline QB4 & & & .813 & & & & & & & & \\
\hline TN5 & & & & .934 & & & & & & & \\
\hline TN3 & & & & .870 & & & & & & & \\
\hline TN1 & & & & .869 & & & & & & & \\
\hline TN2 & & & & .849 & & & & & & & \\
\hline TN4 & & & & .825 & & & & & & & \\
\hline DV1 & & & & & .903 & & & & & & \\
\hline DV2 & & & & & .839 & & & & & & \\
\hline DV3 & & & & & .788 & & & & & & \\
\hline DV4 & & & & & .761 & & & & & & \\
\hline DV5 & & & & & .737 & & & & & & \\
\hline SP1 & & & & & & .903 & & & & & \\
\hline SP2 & & & & & & .844 & & & & & \\
\hline
\end{tabular}


Table 4: Continued

\begin{tabular}{|c|c|c|c|c|c|c|c|c|c|c|c|}
\hline & & & & & & Comp & & & & & \\
\hline & 1 & 2 & 3 & 4 & 5 & 6 & 7 & 8 & 9 & 10 & 11 \\
\hline SP4 & & & & & & .827 & & & & & \\
\hline SP3 & & & & & & .817 & & & & & \\
\hline SP5 & & & & & & .758 & & & & & \\
\hline NL1 & & & & & & & .894 & & & & \\
\hline NL2 & & & & & & & .868 & & & & \\
\hline $\mathrm{NL4}$ & & & & & & & .865 & & & & \\
\hline NL5 & & & & & & & .802 & & & & \\
\hline NL3 & & & & & & & .726 & & & & \\
\hline LK2 & & & & & & & & .891 & & & \\
\hline LK1 & & & & & & & & .844 & & & \\
\hline LK3 & & & & & & & & .826 & & & \\
\hline LK4 & & & & & & & & .767 & & & \\
\hline LK5 & & & & & & & & .680 & & & \\
\hline HT2 & & & & & & & & & .873 & & \\
\hline HT4 & & & & & & & & & .764 & & \\
\hline HT3 & & & & & & & & & .739 & & \\
\hline HT1 & & & & & & & & & .739 & & \\
\hline HT5 & & & & & & & & & .709 & & \\
\hline K1 & & & & & & & & & & .754 & \\
\hline K2 & & & & & & & & & & .724 & \\
\hline K3 & & & & & & & & & & .669 & \\
\hline CD2 & & & & & & & & & & & .886 \\
\hline CD1 & & & & & & & & & & & .756 \\
\hline CD3 & & & & & & & & & & & .755 \\
\hline
\end{tabular}

\subsection{Regression Analysis}

To perform regression analysis, the authors calculated the mean value to represent the dependent variables and the independent variables. The results of the regression analysis assessing the impact of factors on the development of sustainable tourism in the South Central Coast, Vietnam are obtained as follows:

Table 5 shows that all the independent variables affect the dependent variables for the development of sustainable tourism in the South Central Coast of Vietnam (this is concluded through the T-test with Sig level of the Test less than 1\% and $5 \%$ ). Also, the problem of multi-collinearity does not appear in the model. Specifically, the VIF magnification coefficients are all less than 10 (the level is determined with multiple collinearities to be treated).

$\mathrm{R}^{2}$ of the model is $77.9 \%$, proving that the independent variables can explain the high volatility of the dependent variables. Besides, the results of testing the conformity of the regression function through $\mathrm{F}$ statistic from the ANOVA table showed that the model is suitable (the Sig level of the test is very small 0.000). Thus, based on the regression results table, we have a regression equation for factors affecting the development of sustainable tourism in the South Central Coast of Vietnam. 
Table 5: Results of Regression Analysis

\begin{tabular}{|c|c|c|c|c|c|c|c|c|}
\hline \multirow{2}{*}{\multicolumn{2}{|c|}{ Model }} & \multicolumn{2}{|c|}{$\begin{array}{l}\text { Unstandardized } \\
\text { Coefficients }\end{array}$} & \multirow{2}{*}{$\begin{array}{c}\text { Standardized } \\
\text { Coefficients }\end{array}$} & \multirow{2}{*}{$\mathbf{t}$} & \multirow{2}{*}{ Sig. } & \multicolumn{2}{|c|}{ Collinearity Statistics } \\
\hline & & B & Std. Error & & & & Tolerance & VIF \\
\hline \multirow[t]{12}{*}{1} & (Constant) & .036 & .108 & & .331 & .741 & & \\
\hline & CS & .173 & .012 & .374 & 15.002 & .000 & .915 & 1.093 \\
\hline & HT & .160 & .013 & .312 & 12.167 & .000 & .864 & 1.157 \\
\hline & TN & .138 & .010 & .348 & 13.829 & .000 & .900 & 1.111 \\
\hline & $\mathrm{NL}$ & .101 & .011 & .237 & 9.573 & .000 & .930 & 1.076 \\
\hline & SP & .074 & .012 & .169 & 6.219 & .000 & .773 & 1.294 \\
\hline & DV & .027 & .013 & .062 & 2.096 & .037 & .660 & 1.516 \\
\hline & LK & .102 & .012 & .211 & 8.736 & .000 & .973 & 1.028 \\
\hline & QB & .034 & .012 & .077 & 2.872 & .004 & .786 & 1.273 \\
\hline & $\mathrm{HL}$ & .065 & .011 & .143 & 5.747 & .000 & .912 & 1.097 \\
\hline & $C D$ & .120 & .011 & .264 & 10.653 & .000 & .929 & 1.077 \\
\hline & $\mathrm{K}$ & .097 & .014 & .204 & 7.163 & .000 & .703 & 1.422 \\
\hline
\end{tabular}

a. Dependent Variable: The development of sustainable tourism (PTLBV)

$$
\begin{aligned}
\mathrm{PTDLBV}= & 0.036+0.173 * \mathrm{CS}+0.160 * \mathrm{HT}+0.138 * \mathrm{TN} \\
& +0.101 * \mathrm{NL}+0.074 * \mathrm{SP}+0.027 * \mathrm{DV} \\
& +0.102 * \mathrm{LK}+0.034 * \mathrm{QB}+0.065 * \mathrm{HL} \\
& +0.120 * \mathrm{CD}+0.097 * \mathrm{~K}
\end{aligned}
$$

The standardized regression model is defined as follows:

$$
\begin{aligned}
\mathrm{PTDLBV}= & 0.374 * \mathrm{CS}+0.312 * \mathrm{HT}+0.348 * \mathrm{TN} \\
& +0.237 * \mathrm{NL}+0.169 * \mathrm{SP}+0.062 * \mathrm{DV} \\
& +0.211 * \mathrm{LK}+0.077 * \mathrm{QB}+0.143 * \mathrm{HL} \\
& +0.264 * \mathrm{CD}+0.204 * \mathrm{~K}
\end{aligned}
$$

According to the standardized regression model, the CS factor has a strong impact on the dependent variables of the development of sustainable tourism (with the standardized beta coefficient of 0.374), followed by TN, HT, and CD standardized beta numbers being $0.348,0.312$, and 0.264 respectively. The lowest influence on the dependent variable of sustainable development is the DV and QB factors (with standardized beta coefficients of only 0.062 and 0.077 ). And other factors such as NL, SP, LK, HL, and $\mathrm{K}$ have approximately the same influence.

\section{Discussion and Policy Implications}

According to the regression results, 11 factors affect the development of sustainable tourism in the South Central Coast of Vietnam and all have positive effects on statistical significance. However, there are only four factors that strongly affect the development of sustainable tourism in the South Central Coast of Vietnam. Therefore, with limited resources, to promote the development of sustainable tourism in the South Central Coast of Vietnam, the provinces in the region need to focus on resources to improve factors in order of priority which is Institutions and policies for tourism development, Infrastructure, Tourism resources, and the Local community.

First, regarding institutions and policies on tourism development:

Stable political institutions and flexible and open mechanisms and policies play important roles in attracting investment in general and investment in tourism in particular. Therefore, in addition to maintaining the stable institutions of the Government, the provinces in the South Central Coast of Vietnam need to (i) Improve the effectiveness of state management of tourism through the management and master plan of the tourist destinations in the South Central Coast of Vietnam; (ii) Create favorable mechanisms and policies for projects to invest in tourism infrastructure, facilities supporting tourism through BOT and BT investment; (iii) Develop preferential policies for long-term and stable investment, especially for projects of great value, having a pervasive effect from tourism industry to other sectors; (iv) Promote the attraction of foreign investment inflows for tourism development activities; (v) Strengthen association among provinces in the South Central Coast of Vietnam for the policies and activities of tourism development and (vi) Orient strategies for tourism development in the South Central Coast of Vietnam and the construction of tours, routes, tourist attractions and regional tourist areas to raise the region's tourism value chain, especially, in association with the Central Heritage Road. 
Second, with respect to infrastructure:

Infrastructure for tourism includes transport infrastructure and infrastructure for tourists. Therefore, comprehensive development of the transportation and travel infrastructure system, including road, waterways, and air will promote the development of tourism activities in the South Central Coast of Vietnam, especially, the transportation system to important tourist destinations or tourist centers in the South Central Coast of Vietnam. Besides, it is necessary to focus on investment in infrastructure for tourists such as (i) A rich system of tours, routes, tourist attractions, and tourist resorts; (ii) Information technology infrastructure to meet the needs of tourists; (iii) A system of adequate hotels, restaurants, entertainment venues, shopping and entertainment venues and (iv) A system of adequate, clean public toilets, among others.

Third, as regards tourism resources:

To develop the region's sustainable tourism, in addition to exploiting tourism resources, the provinces in the South Central Coast of Vietnam need to closely coordinate to protect tourism resources, including natural and humanistic tourism resources. Management requires a proper organization to conserve resources as well as bring benefits to residents. Therefore, (i) It is necessary to build a model for co-management of tourism resources, where each locality is a level of management that is decentralized for the management of tourism resources (ii) Provinces in the South Central Coast of Vietnam need to regularly inspect and evaluate the current status of historical sites, socio-culture, landscapes, etc. to come up with specific solutions for conservation and restoration. At the same time, each locality in the region has cultural, historical, and artistic heritages which may be similar to or different from one another, so it is necessary for localities in the region to focus on preserving and promoting their cultural values and diversify tourism resources to contribute to different types of tourism.

Fourth, about the local community:

A friendly local community that actively supports tourists will create a cultural and tourist-friendly environment. Therefore, the local authorities of the provinces in the South Central Coast of Vietnam need to create conditions and specific policies to encourage the local community to actively participate in tourism development and business activities to ensure income for the local community to stabilize life, while creating a friendly and safe tourism environment for tourists.

\section{Conclusion}

The results of this study show that 11 factors influence the development of sustainable tourism in the South Central Coast of Vietnam namely Institutions and policies for tourism development, Infrastructure, Tourism resources, Human resources for tourism, Diversity of tourism services,
Relevant support services, Activities of association and cooperation for tourism development, Tourism promotion and encouragement, Tourists' satisfaction, the Local community, and Other factors. At the same time, among the above factors, the factors belonging to the Institutions and policies for tourism development, Infrastructure, Tourism resources, and the Local community strongly influence the development of sustainable tourism in the region. This shows that most of the factors that strongly influence the development of sustainable tourism in the South Central Coast of Vietnam are from policies, infrastructure, resources, and locals.

In addition to the success of the study, the authors also realize that the typical survey of 160 tourism managers and 240 tourists traveling or have participated in tourism activities of the provinces in the South Central Coast of Vietnam to identify factors affecting the development of sustainable tourism did not enable them to reach a complete and firm conclusion. However, despite the aforementioned limitations, the authors of the study still believe that this study has made a very significant contribution to the flow of empirical research in Vietnam on the development of sustainable tourism, which is still a very new and controversial issue in Vietnam.

\section{References}

Azizi, H., Biglari, M., \& Joudi, P. (2011). Assessment of the feasibility of sustainable tourism in urban environments employing the cumulative linear model. Procedia Engineering, 21, 24-33. https://doi.org/10.1016/j.proeng.2011.11.1983

Chamidah, N., Guntoro, B., \& Sulastri, E. (2020). Marketing communication and synergy of Pentahelix strategy on satisfaction and sustainable tourism. Journal of Asian Finance, Economics, and Business, 7(3), 177-190. https://doi. org/10.13106/jafeb.2020.vo17.no3.177

Chen, L. J., \& Chen, J. S. (2011). The motivations and expectations of international volunteer tourists: A case study of "Chinese Village Traditions". Tourism Management, 32(2), 435-442. https://doi.org/10.1016/j.tourman.2010.01.009

Chheang, V. (2013). Tourism and regional integration in Southeast Asia. Japan: Institute of Developing Economies, Japan External Trade Organization.

Clark, J. (1990). Carrying capacity: The limits to tourism. Paper presented to the Congress on Marine Tourism. Hawaii.

Cevat, T. (2001). Challenges of sustainable tourism development in the developing world: The case of Turkey. Tourism Management, 22(3), 289-303. https://doi.org/10.1016/S02615177(00)00060-1

DeKadt, E. (1979). Tourism: Passport to development? Perspectives on the social and cultural effects of tourism in developing countries. Oxford, UK: Oxford University Press.

Dimoska, T., \& Petrevska, B. (2012). Tourism and economic development in Macedonia. Conference: 21 Biennial 
International Congress "Tourism and Hospitality Industry 2012": "New trends in tourism and hospitality management". At: Opatija, Croatia.

Dinh, P. H., Vo, V. N., \& Tran, P. (2018). Quantitative research in Accounting: Auditing. Hanoi, Vietnam: Financial Publishing House.

Dwyer, L., Forsyth, P., \& Papatheodorou, A. (2011). Economics of tourism. Oxford, UK: Goodfellow Publishers Ltd.

Garcia-Melon, M., Gomez-Navarro, T., \& Acuna-Dutra, S. (2012). A combined ANP-Delphi approach to evaluate sustainable tourism. Environmental Impact Assessment Review, 34, 41-50.

Greg, R., \& Derek, H. (2000). Tourism and sustainable community development. London, UK: Routledge

Hareebin, Y. (2020). Factors affecting human capital and innovative entrepreneurial capabilities of tour operators: Evidence from Andaman Coast, Thailand. Journal of Asian Finance, Economics, and Business, 7(10), 359-368. https://doi. org/10.13106/jafeb.2020.vol7.no10.359

Oztürk, H. E., \& Ayda, E. (2010). Environmental governance for sustainable tourism development: Collaborative networks and organization building in the Antalya tourism region. Tourism Management, 31(1), 113-124. https://doi.org/10.1016/j. tourman.2009.01.002

Hollier, R., \& Lanquar, R. (1996). Tourism marketing: Ecotourism and sustainable development: who owns paradise. Washington, DC: Island Press

Hoang, T., \& Chu, N. M. N. (2011). Applied statistics in the social-economic analysis. Hanoi, Vietnam: Labour and Social Publishing House

International Labour Organization (ILO). (2017). Sustainable Tourism: A catalyst for inclusive socio-economic development and poverty reduction in rural areas. https://www.ilo.org/ wcmsp5/-groups/public/---ed_dialogue/---sector/documents/ publication/wcms_601066.pdf

Ko, T. G. (2005). Development of a tourism sustainability assessment procedure: a conceptual approach. Tourism Management, 26(3), 431-445. https://doi.org/10.1016/j. tourman.2003.12.003

Krippendorf, J. (1987). The Holidaymakers: Understanding the impact of leisure and travel. London, UK: Heinemann.

Lisa, R. (2012). Local government: Facilitator or inhibitor of sustainable tourism development? Journal of Sustainable Tourism, 21(1), 80-98. https://doi.org/10.1080/09669582.201 2.680463

Maia, L., Han, B., \& Mikael, B. (2005). The entrepreneurship factor in sustainable tourism development. Journal of Cleaner Production, 13(8), 787-798. https://doi.org/10.1016/j. jclepro.2004.02.043

Muhammet, Y., Levent, A., Peter, B., \& Fevzi, O. (2010). Politics and sustainable tourism development: Can they co-exist? Voices from North Cyprus. Tourism Management. 31(3), 345356. https://doi.org/10.1016/j.tourman.2009.03.016
Mowforth, M., \& Munt, I. (2015). Tourism and sustainability: Development, globalization, and new tourism in the third world. London, UK: Routledge.

Ngo, T. L. (2015). Sustainable development in the new context of globalization, international integration, and climate change. Hanoi, Vietnam: National Political Publishing House.

Nguyen, D. T. (2014). Solutions for the sustainable development of tourism in the Central Highlands. Doctoral thesis. Academy of Social Sciences. Ha Noi, Vietnam.

Nguyen, M. C. (2015). The role of the local government at the provincial level in the sustainable development of tourism in Ninh Binh province. Doctoral thesis. National Economics University, Ha Noi, Vietnam.

Nguyen, V. D. (2013). Organizing tourism activities at some national historical-cultural relics of Hanoi towards sustainable development, Doctoral thesis, National Economics University, Ha Noi, Vietnam.

Nguyen, T., Nguyen, N., \& Nguyen, V. (2019). Identifying factors influencing the profitability of tourist enterprises: Evidence from Vietnam. Management Science Letters, 9(11), 1933-1940.

Nguyen, N. T., Dao, Q. T., Nguyen, C. D., \& Nguyen, T. N. (2020). Potential for linking tourism product development and tourism destinations in Binh Dinh - Phu Yen - Dak Lak - Gia Lai provinces. Proceedings of the National Scientific Conference: Destination Marketing Strategy - International experience and recommendations for Vietnam.

Pham, T. L. (2002). Scientific basis and solutions for sustainable tourism development in Vietnam, State-level scientific research project. Hanoi.

Plog, S. (1972). Why destination areas rise and fall in popularity. Cornell HRA Quarterly, 14(4), 13-16. https://doi.org/ 10.1177/001088047401400409

Purnomo, S., Rahayu, E. S., Riani, A. L., Suminah, S., \& Udin, U. (2020). Empowerment model for sustainable tourism village in an emerging country. Journal of Asian Finance, Economics, and Business, 7(2), 261-270. https://doi.org/10.13106/jafeb.2020. vol7.no2.261

Stonich, S., Sorenson, J., \& Hundt, A. (1995). Ethnicity, class, and gender in tourism developments: the case of the Bay Islands, Honduras'. Journal of Sustainable Tourism, 3(1), 1-28. https:// doi.org/10.1080/09669589509510705

Seldjan T., \& Donald. (2009). Sustainable tourism development: How do destination stakeholders perceive sustainable urban tourism? Sustainable Development, 17(4), 220-232. https://doi. org/10.1002/sd.384

Sedai (2006). Risk, vulnerability, and tourism in developing countries: The case of Nepal. Bochum, Germany: Institute of Development Research and Development Policy (IDRDP), Ruhr-Universit'at Bochum.

Sharpley, R. (2010). Tourism and sustainable development: Exploring the theoretical divide. Journal of Sustainable Tourism, 8(1), 1-19. https://doi.org/10.1080/09669580008667346 
Tsung, H. L. (2013). Influence analysis of community resident support for sustainable tourism development. Tourism Management, 34, 37-46. https://doi.org/10.1016/j.tourman. 2012.03.007

Tirso, M. U., Luis, A. H. M., \& Olga, S. (1992). Analysis of loading capacity for visitation in the wild areas of Costa Rica, San José. Costa Rica: Neotrópica Foundation, Center for Environmental and Political Studies, CEAP.

Tran, H. S. (2011). Development of human resources for tourism in the South Central Coast - Central Highlands. Doctoral thesis, Administrative Academy, Ho Chi Minh National Academy of Politics, Vietnam.

Tisdell, C. A. (2013). Handbook of tourism economics: analysis, new applications and case studies. Singapore: World Scientific Publishing Co.

Uzun, F. V., \& Somuncu, M. (2015). Evaluation of the sustainability of tourism in Ihlara Valley and suggestions. European Journal of Sustainable Development, 4(2), 165-174. https://doi. org/10.14207/ejsd.2015v4n2p165

Viljoen (2007). Adjudicative competence in adolescent defendants: Judges' and defense attorneys' views of legal standards for adolescents in juvenile and criminal court. Psychology Public Policy and Law, 13(3), 204-229. https://doi.org/10.1037/10768971.13.3.204

Vu, D. V., Tran, G. N., Nguyen, H. T. T., \& Nguyen, C. V. (2020). Factors affecting sustainable tourism development in Ba Ria-Vung Tau, Vietnam. Journal of Asian Finance, Economics, and Business, 7(9), 561-572. https://doi. org/10.13106/jafeb.2020.vo17.no9.561

Zhenhua, L. (2003). Sustainable tourism development: A critique. Journal of Sustainable Tourism, 11(6), 459-475. https://doi. org/10.1080/09669580308667216

World Tourism Organization (UNWTO). (2013). Sustainable tourism for development guidebook: Enhancing capacities for sustainable tourism for development in developing countries. Madrid. UNWTO. htttps//doir.org/10.18111/ 9789284415496.

World Travel \& Tourism Council (WTTC). (2017). Sustainability reporting in travel \& tourism. Retrieved from http://www. un.org/sustainabledevelopment/sustainable-developmentgoals/

Wang, Z. X., \& Pei, L. (2014). A systems thinking-based grey model for sustainability evaluation of urban tourism. Kybernetes, 43(3), 462-479. https://doi.org/10.1108/K-07-2013-0137/full/ html

Whelan, T. (1991). Nature tourism: Managing for the environment. Washington, DC: Island Press.

Wray, M., Dredge, D., Cox, C., Buultjens, J., Hollick, M., Lee, D., \& Lacroix, C. (2010). Sustainable regional tourism destinations: Best practice for management, development, and marketing. Australia: CRC for Sustainable Tourism. 